\title{
Sustainable Development Model of CHINA RAILWAY Express
}

\author{
Wei-Bo Huang \\ Education Technology Center \\ Guangdong University of Foreign Studies \\ Guangzhou, China \\ 247031690@qq.com
}

\author{
Xin-Yuan Zhang \\ School of Economics \& Trade \\ Guangdong University of Foreign Studies \\ Guangzhou, China \\ ljh@oamail.gdufs.edu.cn
}

\author{
Zeng-Hui Yang \\ School of Cyber Security \\ Guangdong University of Foreign Studies \\ Guangzhou, China \\ man@mail.gdufs.edu.cn
}

\begin{abstract}
With the case study of ZHENGZHOU and NEW EUROPE, ZHENG NEW EUROPE, the problem on sustainable development of CHINA RAILWAY Expresses in the inland city under the Belt and Road will be solved. Through the SWOT analysis of ZHENG NEW EUROPE, and according to its actual conditions, the perfect internal and external mechanisms were established. By using of the sustainable development model for ZHENG NEW EUROPE, the change of industry from the past self-service oriented to customer or market-demand oriented will be made. CHINA RAILWAY Expresses is a pioneer in logistics and transportation in Henan. It is a significant measure for integration into the Belt and Road.
\end{abstract}

Keywords-The Belt and Road; China Railway Express; SWOT analysis; Sustainable development model

\section{INTRODUCTION}

The national strategy, the Belt and Road is an important direction for the future economic development of China's economic development at a new stage. On March 28, 2015, with the authorization of the State Council, the NDRC, the Foreign Ministry and the Ministry of Commerce jointly released the Vision and Action for Promoting the Building of the Silk Road Economic Belt and the 21st Century Maritime Silk Road, the Belt and Road. China Railway Express will be incorporated into the strategic layout of the Belt and Road, becoming the major thoroughfare of the Belt and Road, also known as the platform for the development of logistics agglomeration [1].

The data of China EU economic and trade, especially of the trade in goods, was released from the European Statistics Bureau. According to the data, China, ranked after the United States, is the EU's second largest trading partner. During the past 10 years, frequent trade between the two sides. From 2010 to 2016, EU imports from China accounted for the proportion of imports increased from 14\% in 2006 to $20 \%$ in 2016 from outside the area. The proportion of exports to China has increased to $10 \%$ from $6 \%$. The EU exports to China almost doubled. China became the third largest service trade partner for the EU, from less than 20 billion euros to 38 billion euros. The import growth was from 17 billion euros to 27 billion euros. The EU's trade surplus with China increased from 2 billion euros to 11 billion euros.

\section{SWOT ANALYSIS OF ZHENG NEW EUROPE}

Opened in 2013, less than one year's time, ZHENG NEW EUROPE stepped on the European class in the first comprehensive impact. Zhengzhou Customs data showed that in the first half of this year, ZHENG NEW EUROPE are the one of the train bound for Europe, passing through the largest cargo port of Ala Shan Kou. A total of 66 CHINA RAILWAY Expresses, 21 columns for the European column, accounting for $31.8 \%$; in the weight of the goods, ZHENG NEW EUROPE transported of goods over the clearance. ZHENG NEW EUROPE achieve the total weight of the RAILWAY Express $40 \%$, only half a year, while Yu New Europe, named Chongqing New Europe, opened the class more than two years after the return of goods to achieve zero breakthrough, its value also accounted for the total value of about four One part. According to the data from Zhengzhou International Lugang Company, as of July 17, 2017, the total number of classes of courses opened by ZHENG NEW EUROPE have reached 42 standard courses, with a total value of 219.9 million U.S. dollars and a cargo volume of 24,678.967 tons, ranking the first in the country Class opened the first column [2].

Based on the data overall, the analysis of SWOT is constructed, as shown in Fig. 1. 


\begin{tabular}{|c|c|}
\hline $\begin{array}{l}\text { - The cost of entering } \\
\text { the EU has fallen } \\
\text { sharply. } \\
\text { - International } \\
\text { cooperation. }\end{array}$ & $\begin{array}{l}\text { Di sadvantage } \\
\text { - The location advantage is } \\
\text { to be optimized. } \\
\text { - Non-controllable factors } \\
\text { on the agreed arrival time } \\
\text { - Management service level } \\
\text { needs to be further } \\
\text { improved. } \\
\text { - Traffic Investment and } \\
\text { Financing Capabilities } \\
\text { need to be further } \\
\text { improved. }\end{array}$ \\
\hline $\begin{array}{l}\text { Opportunities } \\
\text { Opportunities to } \\
\text { reduce operating } \\
\text { hours. } \\
\text { Opportunities for } \\
\text { increased supply. }\end{array}$ & $\begin{array}{l}\text { Challenge } \\
\text { - Establishing FTA Logistics } \\
\text { and Transportation Hubs } \\
\text { - Cooperation Framework } \\
\text { Agreement for Building } \\
\text { Integrated Transport Hub } \\
\text { Demonstration Project. }\end{array}$ \\
\hline
\end{tabular}

Fig. 1 The SWOT Analysis of ZHENG NEW EUROPE

\section{A. Advantages}

1) The cost of entering the EU has fallen sharply:

Statistics show that from Zhengzhou to Europe, China Railway express running time of 15 days, about 25 days more than maritime transport; logistics costs of heavy goods than air transport savings of $80 \%$, light cargo savings of air by about 20\%. The China Railway express sent from Hamburg to Hamburg in Germany have now achieved a two-way full load normalization operation "going back to four times and four times a week." It is understood that in the first quarter, China Europe Trainee Zhengzhou opened 63 flights with a total value of 421 million U.S. dollars.

\section{2) International cooperation:}

Luxembourg International Cargo Airlines, one of the largest cargo airlines in Europe, opened the shipping route from Luxembourg to Zhengzhou in June 2014 and regards Zhengzhou as one of the two global hub airports. At present, it has owned four airports, Luxembourg-Zhengzhou, Luxembourg-Zhengzhou- Chicago, Milan - Zhengzhou three routes.

\section{3) Import and export:}

In 2015, Henan's total annual import and export volume reached 4.6002 trillion yuan RMB, an increase of $15.3 \%$. The increase is $22.3 \%$ over the national average. The exports of Henan reached 268.4 billion yuan RMB, an increase of $11 \%$, higher than the national average of 12.8 percentage points. The imports of Henan reached 191.62 billion yuan RMB, an increase of $21.9 \%$, higher than the national average of 35.1 percentage points. According to Zhengzhou Customs statistics, in 2016, Henan's import and export volume reached 471.47 billion yuan RMB, an increase of $2.6 \%$ over the same period of last year. The scale of import and export of foreign trade stepped into the top 10 in the country for the first time. Emerging industries represented by mobile phones have replaced the traditional industries with exclusive import and export. They become the pillar industries of Henan's foreign trade. Henan has become one of the major distribution centers for China's imports of fruits, seafood products and meat. A number of companies set up logistics centers in Zhengzhou. They are fancy of Zhengzhou's transportation hub status and rapid distribution capabilities. The stock and "second clearance" mode are created by Henan Bonded Logistics Center. The mode has greatly enhance the logistics efficiency. The aviation, high-speed rail, land transport hub and other multimodal transport will play a greater role in Zhengzhou

\section{B. Disadvantage}

1) Location advantages need to be optimized:

First, the advantages of the national transportation location need to be further strengthened. The total amount of comprehensive transportation facilities is still insufficient. As a national integrated transportation hub, Zhengzhou has relatively weak capacity to serve the nationwide diagonal connectivity and needs to be improved in all directions.

\section{2) Non-controllable factors on the agreed arrival time:}

The recent active participation of many cities in the "Belt and Road Initiative" has also boosted the fiery degree in the CHINA RAILWAY Express. The cargo volume has soared. As the number of classes has increased, many key railway nodes have been jammed and their promised transit time can not be respected. The brand's reputation in the international logistics market is bound to suffer.

3) Management service level needs to be further improved:

The low level of management of transportation integration organizations, the insufficient sharing of information, the difficulty of timely response to new production modes, format of operation, market demand and transportation services have become the shortcomings restricting the development of integrated transportation.

4) Traffic Investment and Financing Capabilities need to be further improved:

The mechanism of investment and financing are still not perfect, and social capital, especially non-governmental capital, accounts for a relatively low proportion of investment in transportation construction. Public welfare infrastructure construction and maintenance lack of stable sources of funds.

\section{5) Transport costs are slightly higher:}

The cost of the unit value of ZHENG NEW EUROPE Railway express is slightly higher. Although transportation has become normal, it also faces the problem of the slightly higher transportation time and cost [3].

\section{Opportunities}

1) Opportunities to reduce operating hours:

The biggest benefit to us over traditional shipping is saving on shipping time and saving on inventory time, especially for high value-added products. For consumers, the price of goods is relatively reduced. The reduction of operating time saves the owner's transportation time and the cost of capital accounting for the cost and inventory cost, reduces the cost from the perspective of the supply chain, and makes the product more creative [4]. 
2) Opportunities for increased supply:

With the Belt and Road in-depth implementation, China's trade with other countries along the routes is even closer and its supply of goods will be more adequate. It is estimated that over the next 10 years, the total volume of trade between our country and the Belt and Road countries will increase at an average annual rate of over $10 \%$. By 2025 , the total trade volume will exceed 250 million U.S. dollars. This will not only greatly increase the supply of CEIBS RAILWAY Express, but will also greatly increase the return source.

\section{Challenges}

1) The Challenges of Establishing FTA Logistics and Transportation Hubs:

On March 31, 2017, the State Council issued a circular that Henan is one of the seven new free trade zones. China will speed up the construction of a modern three-dimensional transportation system and a modern logistics system linking north and south and east-west in Henan and will build the free trade area into a modern comprehensive transportation hub serving the Belt and Road construction. The comprehensive reform and begin the experimental field and the inland open economy Demonstration Area.

2) Cooperation Framework Agreement for Building Integrated Transport Hub Demonstration Project:

Recently, the National Development and Reform Commission and the Henan Provincial Government and Zhengzhou Municipal Government signed the Cooperation Framework Agreement for Building a Comprehensive Transport Hub Demonstration Project [5].

One of the world's top 500 companies Microsoft, UPS, DHL and other customers have classes in each class cabin. In February this year, the first trip back to the train class 41 containers full of car accessories and motor cars, high-speed steel plate, from Hamburg, Germany via Erenhot back to Zhengzhou, China's hinterland to Europe to achieve a two-way reciprocating cargo transport in Central Asia.

\section{A Case Study of Zheng New Europe Sustainable DEVELOPMENT MODEL}

From the above, we can see that the sustainable development of ZHENG NEW EUROPE class train is an important measure for Zhengzhou to integrate into the national strategy of the Belt and Road. During the operation period, the progress of ZHENG NEW EUROPE class has made considerable progress. The geographical advantages need to be optimized. Some problems still exist in terms of cost and expense [6]. In order to fundamentally solve the internal bottlenecks and external obstacles in the process of running RAILWAY Express and eventually achieve a smooth and an efficient normal operation, it is necessary to build a relatively complete and sustainable mechanism for development from both the internal and external aspects, and more specifically in other words, it is transforming the industry from self-serviceoriented to customer-oriented or market-driven. The sustainable development model of CHINA RAILWAY Express is proposed, as shown in Fig. 2.

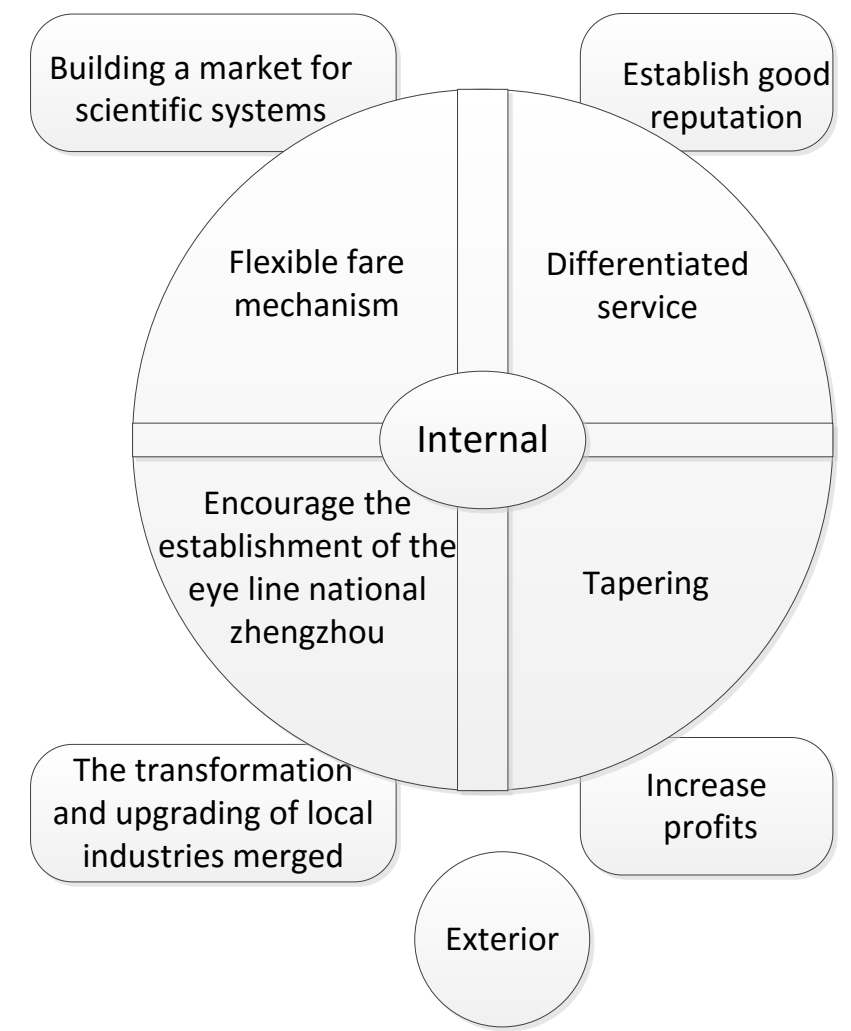

Fig. 2 The Sustainable Development Model of CHINA RAILWAY Express

\section{A. Flexible fare mechanisms help to build a market for scientific systems}

The flexible fare for market changes is an important prerequisite for Zhengzhou's efforts to achieve sustainable development and ahead of other CHINA RAILWAY Express. The rational use of price discrimination strategy, marketoriented pricing mechanism and fare system of scientific system and the increase of fare flexibility of high-speed railway will be conducive to further stimulating the intrinsic motivation and market vitality in the operation of railway enterprises, forming a benign competition mechanism and promoting high-speed The market competitiveness of the railway, to ensure the sustainable development of high-speed railway industry. Fares are calculated according to mileage science, large concessions, discounted by the number of times, for different customers in accordance with different standards for fair and open pricing effectively promote the construction of a scientific system of the market so that customers are willing to experience .

\section{B. Differentiated services help to establish a good reputation}

We should consider the most important issues: how many customers give priority to choose the ZHENG NEW EUROPE how to display their own advantages to customers gaining more favor themselves, which are the new operation of the train after gradually getting back on track.

The higher service standard which is different from other China Railway Express is also give the first priority for customers to consider .Every service provided in the operation 
of a train should not be isolated and random but should be a systematic and standardized service process. The service system needs to establish a reasonable workflow and also need to be protected by means of modern technology work flow, so that ZHENG NEW EUROPE class service standards are available. At present, the RAILWAY Express have been seriously delayed in various circumstances due to the insufficient capacity of the railway infrastructure.

\section{Integration of local factories and factories along the country's borders}

The shortage of supply and the imbalance of return sources are also obstacles to the development of the CHINA RAILWAY Express. For the Zhengzhou-Central Plains inland hub city, not only attract more customers but also have a stable source of supply within their own control. To discuss, build, share overseas distribution base. Encourage outstanding enterprises to go global, invest and build factories in countries along the line, and seek cooperation with the Silk Road Economic Belt to strengthen project support and investment to drive trade. Establish an overseas warehouse in key eyelid countries, and create a distribution center, exhibition center and cooperation demonstration area for the EU-China Baotou goods.

\section{Gradually reduce subsidies and increase profits}

Increasing supply does not mean that as many as possible go sources. The Economic Scale of CEIBS reflects the CEIBS's learning curve effect as the number of classes increases. The result is a decline in long-run average total cost. The pursuit of economies of scale goal is to obtain the best economic efficiency of the scale of production, so that caused the relative shortage of backhaul sources of one of the reasons is the scale has expanded to a certain extent, resulting in increased congestion of lines and stations, the venue facilities Stricter tests that result in a gradual reduction in marginal benefits may lead to economies of scale and may require more government subsidies. In order to increase profits, it is necessary to focus on supporting certain industries that can bring other benefits and give support to the fund during the cultivation period of the EU-China market. In particular, we must focus on supporting the industry's relevance and drive.

\section{CONCLUSION}

From the perspective of the national strategy of the strategic layout of the Belt and Road, CHINA RAILWAY Express have elevated the development of a city and region to an important part of the Belt and Road. The internal and external mechanisms of ZHENG NEW EUROPE are consummated according to their actual conditions. The sustainable development model for ZHENG NEW EUROPE is put forward to make the industries change from self-service oriented to customer and market demand-oriented. Zhengzhou, the Central Plains transportation hub, is an opportunity to help them at a higher point of the origin through the CHINA RAILWAY Express. More resources to gather within the space promote the flow of information flow of people flow. Gradually, the overall efficiency of subsidies will be found.

\section{ACKNOWLEDGEMENT}

This research was financially supported by the 2017 Innovation Training Project for College Students of Guangdong University of Foreign Studies.

\section{REFERENCES}

[1] W. J. Li, "The vision and action of the maritime Silk Road in twentyfirst Century," Country Agriculture Farmers, China, vol. 3, pp. 82-87, March 2015. (In Chinese)

[2] D. He, W. Ch. Li, "Port city central RAILWAY Express mechanism and Countermeasure of sustainable development -- Based on the Yong New Europe RAILWAY Express case study," China Business and Market, China, vol. 30, pp. 105-111, October 2016. (In Chinese)

[3] X. P. Fu, X. Zhang, M. Zou, D. F. Fan, "A comparative analysis of the economy of the CHINA RAILWAY Express based on the value model," Railway Transport and Economy, China, vol. 38, pp. 1-5, November 2016. (In Chinese)

[4] R. Chen, "The analysis of SWOT integration on the Han New Europe in the CHINA RAILWAY Express," China Market, China, vol. 43, pp. 9196, October 2015. (In Chinese)

[5] Y. B. Wang, "Research on the construction and development plan of CHINA RAILWAY Express," Railway Transport and Economy, China, vol. 39, pp. 41-45, January 2017. (In Chinese)

[6] X. D. Jiang, H. M. Fan, "The Operation Problems and Countermeasures in the CHINA RAILWAY Express under the Strategy of The Belt and Road," Practice in Foreign Economic Relations and Trade, China, pp. 28-30, January 2017. (In Chinese) 